\title{
Evaluation of the relation between epicardial adipose tissue and hepatosteatosis with coronary atherosclerosis using multidetector computed tomography
}

\author{
Epikardiyal yağ dokusu ve hepatosteatoz ile koroner ateroskleroz arasındaki ilişkinin \\ çok kesitli bilgisayarlı tomografi ile değerlendirilmesi
}

\author{
๑DElif Uzun Ata, @Nilgün Işıksalan Özbülbül \\ Ankara Bilkent City Hospital, Ankara, Turkey
}

Cite this article as/Bu makaleye atıf için: Uzun Ata E, Işıksalan Özbülbül N. Evaluation of the relation between epicardial adipose tissue and hepatosteatosis with coronary atherosclerosis using multidetector computed tomography. J Med Palliat Care 2021; 2(4): 143-148.

\begin{abstract}
Background: In this study, the relationship of CAD (coronary artery disease) with EAT (epicardial adipose tissue) volume and hepatosteatosis were investigated by using multidetector computed tomography (MDCT).

Material and Method: EAT (Epicardial Adipose Tissue) volume, CCS (coronary calcium score) and CT density of liver (CTDL) were measured by using 64-detector computed tomography in 96 patients who were clinically referred for the evaluation of CAD. The relationship between EAT volume, CCS, CTDL and their effectiveness in detecting coronary heart disease were investigated. Data analysis was done with MedCalc (Version 9.6.2.0) package program.

Results: CCS (AUC=0.866) and EAT volume (AUC=0.672) were significantly effective in determination of CAD. The diagnostic accuracy of CCS in detecting CAD was higher than of EAT volume. EAT volume was higher in patients with CAD $\left(85.81 \pm 34.51 \mathrm{~cm}^{3}\right)$, compared to patients without CAD $\left(68.38 \pm 29.23 \mathrm{~cm}^{3}\right)(\mathrm{P}=0.0119)$. CTDL in patients with CAD $(58.74 \pm 12.22 \mathrm{HU})$ was significantly lower than in patients without CAD $(63.02 \pm 8.93)(\mathrm{P}=0.0553)$. There was no statistically significant relationship between EAT volume and CCS ( $\mathrm{r}=0.1620$, $\mathrm{P}=0.1148)$, EAT volume and CTDL ( $\mathrm{r}=0.0046, \mathrm{P}=0.9648)$, and CCS and CTDL $(\mathrm{r}=0.0109, \mathrm{P}=0.9162)$.

Conclusion: There was no relationship between EAT volume, CTDL and CCS. EAT volume is higher in patients with CAD than in patients without CAD. EAT volume had moderate but lower diagnostic power than CCS, to determine CAD.
\end{abstract}

Keywords: Coronary atherosclerosis, epicardial adipose tissue, hepatosteatosis, MDCT

\section{ÖZ}

Giriş: Bu çalışmada çok kesitli bilgisayarlı tomografi (ÇKBT) kullanılarak, epikardiyal yağ doku volümü ve hepatosteatozun koroner arter hastalığı ile ilişkisi araştırıldı.

Gereç ve Yöntem: Koroner arter hastalığı (KAH) ön tanısıyla koroner bilgisayarlı tomografi (BT) anjiyografi tetkiki yapılan 96 hastada epikardiyal yağ volümü, koroner kalsiyum skoru ve karaciğer BT dansitesi ölçüldü. Epikardiyal yağ volümü, koroner kalsiyum skoru ve karaciğer dansitesi arasındaki ilişki ile koroner kalp hastalığını saptamadaki performansları araştırıldı. Verilerin analizi MedCalc (Version 9.6.2.0) paket programı ile yapıldı.

Bulgular: Koroner kalsiyum skoru $(\mathrm{EAA}=0,866)$ ve epikardiyal yağ volümü $(\mathrm{EAA}=0,672)$ koroner aterosklerozu belirlemede istatiksel olarak etkin bulundu. Koroner arter hastalığını saptamada koroner kalsiyum skoru ölçümünün tanısal etkinliği, epikardiyal yağ volümü ölçümünün tanısal etkinliğinden yüksek bulundu. KAH olanlarda epikardiyal yağ volümü $\left(85,81 \pm 34,51 \mathrm{~cm}^{3}\right), \mathrm{KAH}$ olmayanlara göre $\left(68,38 \pm 29,23 \mathrm{~cm}^{3}\right)$ daha yüksek bulundu ( $\mathrm{P}=0,0119)$. KAH olanlarda karaciğer BT dansitesi $(58,74 \pm 12,22 \mathrm{HU}), \mathrm{KAH}$ olmayanlara göre $(63,02 \pm 8,93)$ istatistiksel olarak sınırda düşük bulundu ( $\mathrm{P}=0,0553)$. Epikardiyal yağ volümü ile kalsiyum skoru arasında $(\mathrm{r}=0,1620, \mathrm{P}=0,1148)$, epikardiyal yağ volümü ile karaciğer BT dansitesi arasında $(\mathrm{r}=0,0046, \mathrm{P}=0,9648)$ ve kalsiyum skoru ile karaciğer $\mathrm{BT}$ dansitesi arasında $(\mathrm{r}=0,0109, \mathrm{P}=0,9162)$ istatistiksel olarak anlamlı ilişki saptanmadı.

Sonuç: Epikardiyal yağ volümü, hepatosteatoz ve koroner kalsiyum skoru arasında bir ilişki yoktur. Epikardiyal yağ volümü KAH olanlarda, KAH olmayanlara göre daha yüksektir. Epikardiyal yağ volümü ölçümü, KAH’ı göstermede orta derecede tanısal etkinliğe sahiptir ancak gücü koroner kalsiyum skorlamasına göre daha azdır.

Anahtar Kelimeler: Koroner ateroskleroz, epikardiyal yağ doku, hepatosteatoz, ÇKBT 


\section{INTRODUCTION}

Obesity is an important health problem with high mortality rates (1-3) due to its metabolic and cardiovascular complications (4). The obesity related cardiovascular complications are related to visceral adipose tissue, which is exerting deleterious effects by secreting metabolically active, proatherogenic, proinflammatoryand prothromboticbioactivemolecules (1-7). Epicardial adipose tissue (EAT) is similar to visceral fat tissue, in that, it has better association with cardiovascular diseases than subcutaneous fat tissue (810). Furthermore, EAT is thought to have a contribution in the pathogenesis of coronary artery disease because of its proximity to coronary artery adventitia (11-15). The amount of EAT was associated with metabolic syndrome, cardio-metabolic risk factors and coronary artery disease (CAD) (16).

Hepatosteatosis is recognized as a marker that represents the increase of total body fat (17). The quantitative assessment of hepatosteatosis can be made with high accuracy through liver parenchyma density measurement by using multidetector computed tomography (MDCT) (18). However, there is no consensus up to date about the relationship between hepatosteatosis with epicardial adipose tissue (EAT) and coronary calcium scoring (CCS).

The aim of the present study was to investigate the relationship between EAT volume and hepatosteatosis as a marker of general body fat deposition and CAD.

\section{MATERIAL AND METHOD}

\section{Study Population}

This study was conducted in accordance with the Principles of Helsinki Declaration and after study protocol approval by Ankara Yüksek İhtisas Training and Research Hospital Ethics Committee (Date: 26.10.2010, Decision No: 245).

The study population was consisted of 96 patients (60 male, 36 female) aged between 23 to 76 (mean $53.5 \pm 11.2$ years) who were referred for the clinical evaluation for CAD by MDCT. The exclusion criteria for MDCT were previous coronary artery by-pass surgery which can influence EAT volume and implanted coronary artery stents which may affect CCS. The patients who had known liver failure or a liver mass which may deteriorate the measurement of CT density of liver (CTDL) were also excluded. The demographic data of all patients were recorded using hospital database software. Previous diagnosis of diabetes mellitus, hypertension, hyperlipidemia, presence of family history of these diseases and current smoking status were recorded.

\section{MDCT Examination}

Coronary CT angiography examinations were performed by using 64-detector MDCT (Toshiba Aquillion 64, Tokyo, Japan). The patients were monitored before the study for the assessment of heart rate and rhythm. The patients which had the resting heart rate above 70 beats per minute were received metoprolol (50-100 mg) per orally, 90-120 minutes before the MDCT scan. The patients were excluded who had irregular rhythms such as ectopic pulses, atrial fibrillation, ventricular block, or the resting heart rate above 70 beats per minute.

All image acquisitions were performed in supine position in inspiratory breath-hold with mild hyperventilation. Firstly, pre-contrast images were acquired prospectively which started at carina extended to the $1 \mathrm{~cm}$ below the heart base with $3-\mathrm{mm}$ collimation, $120 \mathrm{kV}, 60 \mathrm{~mA}$. After that, the level of coronary artery origins was detected on pre-contrast images and started to scan from $1-\mathrm{cm}$ above the origins of the coronary artery to the $1-\mathrm{cm}$ below of the base of heart with retrospective electrocardiographic gating. The imaging parameters were a slice collimation of 64 $\mathrm{mm} \times 0.5 \mathrm{~mm}$, gantry rotation time of $330 \mathrm{~ms}$, tube voltage of $120 \mathrm{kV}$, and tube current of $250-600 \mathrm{~mA}$. Contrast material was intravenously injected $(90 \mathrm{~mL}$ nonionic contrast material, with $370 \mathrm{mg} \mathrm{I} / \mathrm{mL}$ at a rate of $5 \mathrm{~mL} / \mathrm{s}$ ) through an $18 \mathrm{G}$ cannula placed into the right median antecubital vein. Image acquisition was triggered automatically at $180 \mathrm{HU}$ in the descending aorta.

After acquisition of the raw data, images were reconstructed at $70 \%$ of the $\mathrm{R}-\mathrm{R}$ interval which was the most motion-free phase of the cardiac cycle. These images were transferred to a workstation for processing (Vitrea, Version 3.2, Vital Images, Minneapolis, USA).

\section{Image Evaluation}

Pre-contrast axial images were evaluated by a radiologist using a dedicated Workstation (Vitrea, Version 3.2, Vital Images, Minneapolis, USA) in order to search for calcific plaque presence within the coronary arteries. If a calcific plaque was detected, it was marked, and then total calcium score (Agatston score) was calculated automatically by using Smartscore (GE Medical Systems, USA). The overall Agatston score was documented for each coronary vessel in each patient. Epicardial adipose tissue was defined as the fatty area which lies between the outer surface of myocardium and the parietal pericardium on pre-contrast images at a dedicated Workstation (Vitrea, Version 3.2, Vital Images, Minneapolis, USA). Firstly, EAT borders were determined by tracing parietal pericardium manually from aortic root to the apex in every four slices on 
pre-contrast axial images with $3-\mathrm{mm}$ thickness. Secondly, attenuation values were adjusted between $-30 \mathrm{HU}$ and $-190 \mathrm{HU}$. Afterwards, by means of using computer software, EAT volume $\left(\mathrm{cm}^{3}\right)$ was calculated automatically for the selected area.

After the evaluation of coronary CT angiography images, CAD was diagnosed if the patients had $50 \%$ or more stenosis at least in one coronary artery. The study population was divided into CAD positive and CAD negative groups. In order to scan for hepatosteatosis, three density measurements of the liver (HU) were obtained from the liver parenchyma in the scanning area on precontrast images with a ROI of approximately $1 \mathrm{~cm}^{2}$ and the mean value was recorded.

\section{Statistical Analysis}

All statistical analyses of our study were performed using MedCalc (Version 9.6.2.0) software program. Numerical values were defined as mean \pm standard deviation. The power of EAT volume and CTDL of predicting CAD diagnosis was investigated with ROC (Receiver Operating Characteristic) analysis. The correlations between EAT volume, CCS and CTDL were tested with Pearson correlation test. If $\mathrm{P}$ value was $<0.05$, it was considered as statistically significant.

\section{RESULTS}

Demographic characteristics of the patients, and the risk factors for the prediction of CAD were shown in the Table 1. The value of EAT volume ranged from $23.4 \mathrm{~cm}^{3}$ to $184.5 \mathrm{~cm}^{3}$ (mean $74.1 \pm 31.8 \mathrm{~cm}^{3}$ ). The measurements of CCS ranged from 0 to 1304 (mean $103.9 \pm 229.0$ ). The values of CTDL ranged from $23.3 \mathrm{HU}$ to $77.3 \mathrm{HU}$ (mean $61.7 \pm 10.2 \mathrm{HU}$ ).

The ROC curves were generated, and area under curve (AUC) was calculated for determining the accuracy of CCS, EAT volume and CTDL to indicate CAD (Figure 1, Table 2). CCS $(\mathrm{AUC}=0,866)$ and $\mathrm{EAT}$ volume (AUC $=0,672$ ) were statistically effective in detecting CAD (Table 3). Diagnostic accuracy of CCS in detecting $\mathrm{CAD}$ was higher according to ROC analysis $(\mathrm{P}=0.010)$ than of EAT volume measurement (Table 4).

EAT volume was higher in patients with CAD $\left(85.81 \pm 34.51 \mathrm{~cm}^{3}\right)$ when compared to patients without CAD $\left(68.38 \pm 29.23 \mathrm{~cm}^{3}\right)$ (Figure 2). CTDL in patients with CAD $(58.74 \pm 12.22 \mathrm{HU})$ was significantly lower when compared to those without CAD $(63.02 \pm 8.93)(\mathrm{P}=$ 0.0553) (Figure 3).

There were no statistically significant correlations between EAT volume and CCS ( $\mathrm{r}=0.1620, \mathrm{P}=0.1148)$, EAT volume and CTDL $(\mathrm{r}=0.0046, \mathrm{P}=0.9648)$, and CCS and CTDL ( $\mathrm{r}=0.0109, \mathrm{P}=0.9162)$ (Figure 4).

\section{Table 1. Demographic characteristics and risk factors of patients}

\begin{tabular}{|c|c|}
\hline Age, years ${ }^{\star}$ & $53.5 \pm 11.7$ \\
\hline Gender $(\text { male })^{* *}$ & $60(63 \%)$ \\
\hline Weight $(\mathrm{kg})^{\star}$ & $81.2 \pm 11$ \\
\hline Height $(\mathrm{cm})^{*}$ & $168 \pm 8$ \\
\hline $\operatorname{BMI}\left(\mathrm{kg} / \mathrm{m}^{2}\right)^{\star}$ & $28.8 \pm 3.9$ \\
\hline Diabetes mellitus ${ }^{\star *}$ & $17(17.7 \%)$ \\
\hline Hypertension ${ }^{\star *}$ & $41(43.7 \%)$ \\
\hline Hyperlipidemia ${ }^{* *}$ & $47(49.4 \%)$ \\
\hline Current smoking ${ }^{\star \star}$ & $48(50.52 \%)$ \\
\hline Family history of $\mathrm{CAD}^{* *}$ & $55(58.3 \%)$ \\
\hline $\mathrm{CCS}^{*}$ & $103.9 \pm 229.0$ \\
\hline $\mathrm{CAD}^{*}$ & $30(31.5 \%)$ \\
\hline
\end{tabular}

${ }^{*}$ Mean $\pm \mathrm{SD},{ }^{* *} \mathrm{n}(\%), \mathrm{BMI}:$ Body mass index, CAD: Coronary artery disease, CCS: Coronary calcium score, SD: Standard deviation

Table 2. Comparison of areas under ROC curve of EAT volume, CCS and CTDL in detecting coronary artery disease

\begin{tabular}{|lcc|}
\hline Parameters & $\begin{array}{c}\text { The difference between } \\
\text { AUCs }(95 \% \text { CI) }\end{array}$ & P value \\
\hline CCS - EAT volume & $0.194(0.047-0.341)$ & 0.010 \\
EAT volume - CTDL & $0.092(-0.068-0.253)$ & 0.260 \\
CCS - CTDL & $0.286(0.143-0.429)$ & $<0.001$ \\
\hline $\begin{array}{l}\text { CCS: Coronary calcium score, CTDL: CT Density of liver, EAT: Epicardial adipose } \\
\text { tissue }\end{array}$ &
\end{tabular}

Table 3. Diagnostic accuracy of EAT volume, CCS and CTDL in detecting coronary artery disease

\begin{tabular}{|lc|}
\hline Parameters & Area under ROC curve (95\% CI) \\
\hline EAT Volume & $0.672(0.569-0.765)$ \\
CCS & $0.866(0.781-0.927)$ \\
CTDL & $0.580(0.475-0.680)$ \\
\hline $\begin{array}{l}\text { CCS: Coronary calcium score, CTDL: CT Density of liver, EAT: Epicardial adipose } \\
\text { tissue }\end{array}$ \\
\hline
\end{tabular}

\begin{tabular}{|lcc|}
\hline \multicolumn{3}{|l|}{ Table 4. Correlation coefficients of EAT volume, CCS and CTDL } \\
\hline \multicolumn{1}{|c|}{ Parameters } & r & P value \\
\hline CCS - EAT Volume & 0.1620 & 0.1148 \\
EAT Volume - CTDL & 0.0046 & 0.9648 \\
CCS - CTDL & 0.0109 & 0.9162 \\
$\begin{array}{l}\text { CCS: Coronary calcium score, CTDL: CT Density of liver, EAT: Epicardial adipose } \\
\text { tissue }\end{array}$ & \multicolumn{3}{|c}{} \\
\hline
\end{tabular}

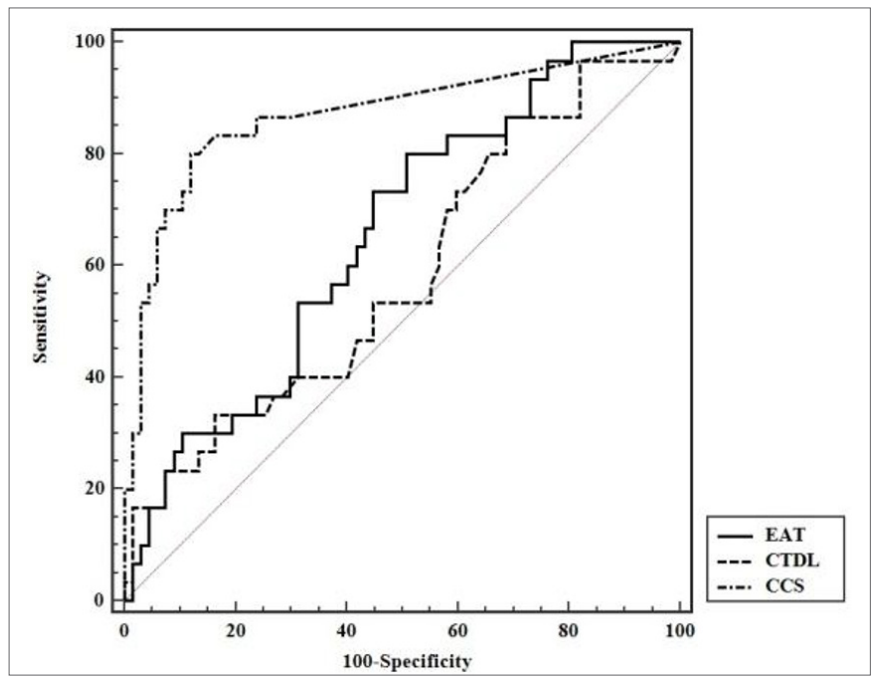

Figure 1. Graph shows the comparison of receiver operating characteristic curve (ROC) for EAT, CTDL, and CCS to detect CAD 


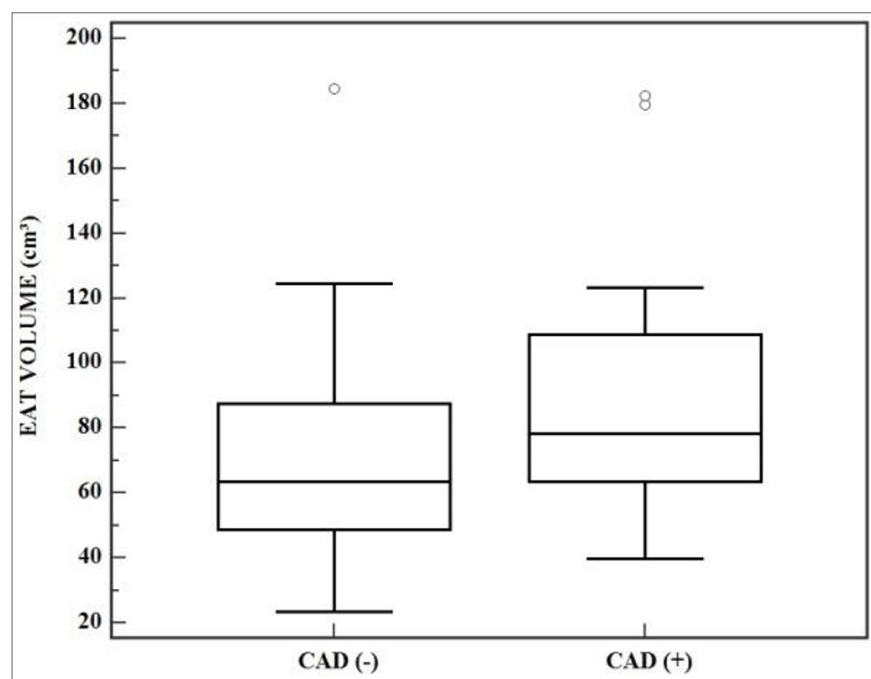

Figure 2. Graph shows EAT volumes in patients with CAD and without $\mathrm{CAD}$

\section{DISCUSSION}

Several non-invasive imaging modalities such as transthoracic echocardiography (TTE), MDCT and magnetic resonance imaging (MRI) have been used for the measurement of EAT volume. Among these, the most commonly used method in clinical practice and in studies which evaluated the relationship between EAT and CAD was TTE $(8,14,19,20)$. The measurement of EAT volume with TTE is more practical compared to that with MDCT. On the other hand, echocardiography is quite dependent on acoustic windows thus it might not provide sufficient EAT windows surrounding all cardiac segments and compartments. MDCT has some advantages like having high temporal and spatial resolution, providing 3-dimensional imaging of heart and epicardial surface.

It is well known that the increased body fat is associated with CAD. In particular, many studies showed that abdominal visceral fat deposition and CAD risk were strongly correlated $(5,19)$. Visceral adipose tissue is considered as a complex endocrine organ which produces various substances causing local and systemic effects. It has the capability of secreting various bioactive molecules that have proatherogenic, proinflammatory and prothrombotic effects $(6,7,9,11)$.

Epicardial adipose tissue protects coronary artery from tension or torsion and serves energy to the myocardium $(9,10)$. Apart from physiological functions, EAT is also visceral fat deposition which has a variable amount and distribution pattern situated beneath epicardium around both ventricles. Hence as there is no fascia-like structure between EAT and myocardium, it was hypothesized that substances produced in adipocytes and macrophages infiltrating epicardial adipose tissue affect adjacent myocytes with paracrine mechanisms. Recent studies have shown that increased EAT volume might have been

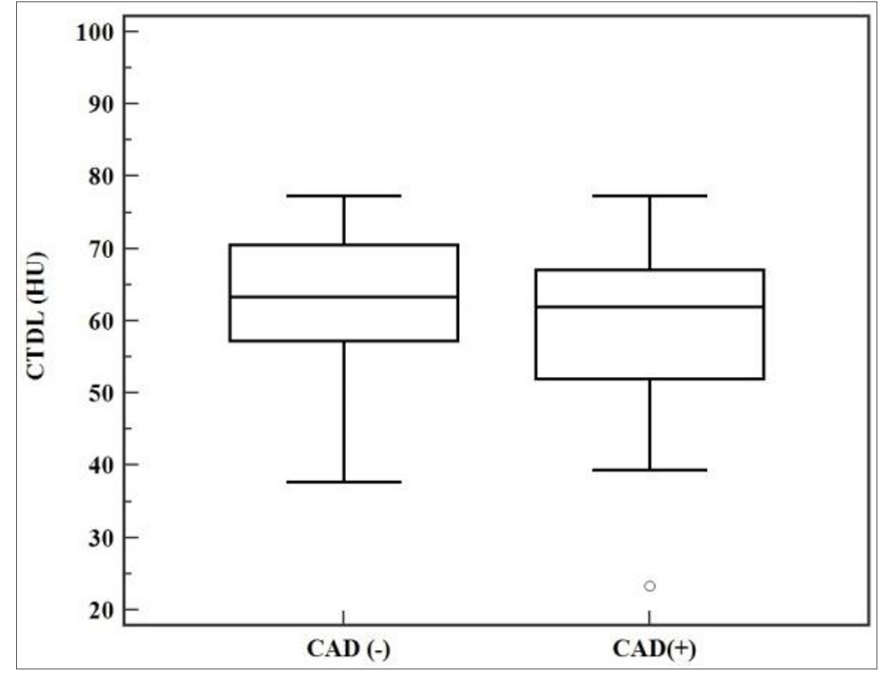

Figure 3. Graph shows CTDL (HU) in patients with CAD and without $\mathrm{CAD}$.

an important risk factor for cardiac diseases $(8,12,13)$. It has been proved that proinflammatory cytokine concentrations were increased in EAT (6,9-11). Some other studies also showed that EAT played an important role in CAD development by secreting proinflammatory molecules which facilitated the progression of coronary artery atherosclerosis $(9,11,13,15,16)$.

There were many studies which investigated the relationship between EAT and CAD with controversial results (12-15). In some of them, the authors used the maximum thickness of EAT on MDCT images while others measured EAT around the heart on echocardiographic images $(21,22)$. EAT thickness varies depending on the location around the heart, therefore the calculation of the EAT volume using the MDCT images gives more accurate information. In our study, we performed the calculation of the EAT volume on diastolic phase MDCT images which were nearly motion-free. Although there was a mild relationship between EAT volume and the severity of CAD, a previous study found that increase in severity of coronary atherosclerosis had no relationship with an increase in EAT volume (13). According to our results, EAT volume had an efficacy to determine CAD which was compatible with the previous studies $(14,15,16,22)$. We also found that EAT volume was higher in patients with CAD than without CAD.

According to current data, it is not exactly known which type of fat tissue, such as EAT, abdominal obesity or visceral fat, plays the most important role leading to $\mathrm{CAD}$. The relationship between central obesity and CAD can be explained by the fact that EAT storage is increased in centrally obese patients. It is still unclear that if EAT is a marker which is a mere sign for abdominal obesity or if abdominal visceral fat deposition causes pathogenic cardiac fat deposition. 
CCS is a useful method for evaluating the degree of coronary atherosclerosis. Although researchers suggested to include CCS to the conventional cardiovascular risk assessment (23), combining calcium scoring with conventional estimation methods could not achieve any predictive power (24). CCS has not been recommended to be used in daily practice in asymptomatic patients. However, CCS could be useful in some selected patients.

In a study carried out with Djaberi et al. (15) mean EAT volume was found to be significantly higher in patients with CCS over 10 compared to patients with a score of equal or lower than 10. They also demonstrated that increase in the degree or severity of atherosclerosis had not caused significant increase in EAT volume. If the risk factors are taken into an account, EAT volume might be used as an indicator of coronary atherosclerosis. Conversely, in another study, Chaowalit et al. (13) showed no relation between EAT thickness and angiographically confirmed CAD.

In our study, we did not find significant relationship between EAT volume and CCS. This could be explained by properties of our study population. The mean EAT volume in our study population ranged between 23.4 $\mathrm{cm}^{3}$ and $184.5 \mathrm{~cm}^{3}$. If we had more patients in our study population which had increased EAT volume, we may have found a significant relationship between EAT volume and CCS.

In our study, we defined CAD if a patient's stenosis degree was $50 \%$ and above at least in one coronary artery and found the diagnostic accuracy of EAT volume measurement was lower than CCS for detecting CAD. Additionally, we obtained no correlation between CCS and EAT volume. Our results showed that EAT volume measurement does not indicate the severity of coronary atherosclerosis, therefore, it is not suitable for detecting CAD.

Increased EAT volume in patients with CAD does not imply a cause-and-effect relationship between CAD and EAT volume. Since EAT volume expands with age and visceral adiposity, CAD incidence also increases with advanced age and visceral fat deposition $(13,14,21,23)$.

It has been claimed that fat deposition in liver could also be responsible for developing CAD. Alper et al. (25) found a relationship between NAFLD and CAD detected with coronary angiography. Furthermore, Matteoni et al. (26) demonstrated that cardiovascular mortality was increased in patients diagnosed with NAFLD. On the other hand, in our study we did not find significant relationship between CTDL and CAD. However, regarding the CCS in our study population, we had quite a few patients with CAD. Additionally, the mean value of EAT volume was not high. It was not a surprise for us that our study population had low EAT volume and had CCS was mostly below 400 . Hence, we could say that our study population was in low-risk category in terms of cardiac pathology and cardiac fat deposition. In this context, low abdominal visceral adiposity in our study population might have been the reason for us not to have found a statistically significant relationship between CAD and CTDL and EAT volume. Further studies with large number of CAD patients with wide range of atherosclerosis degree and EAT volume are needed to clarify the relation between CAD and CTDL.

There are some limitations in our study. Firstly, we only included the patients referred to our department for cardiac $\mathrm{CT}$, therefore we could not measure abdominal visceral fat volume. Secondly, the dome of the liver and a small portion of the right lobe could only be observed on pre-contrast images so the CTDL measurements could only be performed in these parts of liver. The ideal CTDL measurements should cover the whole liver, which requires extended scanning area and necessitates more radiation exposure of the patient. Thirdly, the markers of inflammation which may support our results were not determined.

\section{CONCLUSION}

We did not find a significant relationship between EAT volume, CTDL and CCS which is considered as a predictive marker of coronary atherosclerosis. Mean EAT volume is higher in patients with CAD compared to patients without CAD. Finally, EAT volume showed moderate but lower diagnostic power than CCS to determine $\mathrm{CAD}$.

\section{ETHICAL DECLARATIONS}

Ethics Committee Approval: This study conducted after study protocol approval by Ankara Yüksek İhtisas Training and Research Hospital Ethics Committee (Date: 26.10.2010, Decision No: 245).

Informed Consent: Because the study was designed retrospectively, no written informed consent form was obtained from patients.

Referee Evaluation Process: Externally peer-reviewed.

Conflict of Interest Statement: The authors have no conflicts of interest to declare.

Financial Disclosure: The authors declared that this study has received no financial support.

Author Contributions: All of the authors declare that they have all participated in the design, execution, and analysis of the paper, and that they have approved the final version. 


\section{REFERENCES}

1. Kershaw EE, Flier JS. Adipose tissue as an endocrine organ. J Clin Endocrinol Metab 2004; 89: 2548-56.

2. Iacobellis G, Leonetti F, Mario UD. Images in cardiology: massive epicardial adipose tissue indicating severe visceral obesity. Clin Cardiol 2003; 26: 237.

3. Sharma AM. Adipose tissue: a mediator of cardiovascular risk. Int J Obes Relat Metab Disord 2004; 26: S5-S7.

4. Carr DB, Utzschneider KM, Hull RL, et al. Intra-abdominal fat is a major determinant of the National Cholesterol Education Program Adult Treatment Panel III criteria for the metabolic syndrome. Diabetes 2004; 53: 2087-94.

5. Yusuf S, Hawken S, Ounpuu $S$ et al. Obesity and the risk of myocardial infarction in 27,000 participants from 52 countries: A case-control study. Lancet 2005 Nov 5; 366: 1640-9.

6. Kremen J, Dolinkova M, Krajickova J, et al. Increased subcutaneous and epicardial adipose tissue production of procytokines in cardiac surgery patients: possible role in postoperative insulin resistance. J Clin Endocrinol Metab 2006; 91: 4620-7.

7. Libby P, Ridker PM, Maseri A. Inflammation and atherosclerosis. Circulation 2002; 105: 1135-43.

8. Iacobellis G, Ribaudo MC, Assael F, et al. Echocardiographic epicardial adipose tissue is related to anthropometric and clinical parameters of metabolic syndrome: A new indicator of cardiovascular risk. J Clin Endocrinol Metab 2003; 88: 5163-8.

9. Mazurek T, Zhang L, Zalewski A, et al. Human epicardial adipose tissue is a source of mediators. Circulation 2003; 108: 2460-6.

10. Rabkin SW. Epicardial fat: properties, function and relationship to obesity. Obes Rev 2007; 8: 253-61.

11. Baker AR, Silva NF, Quinn DW, et al. Human epicardial adipose tissue expresses a pathogenic profile of adipocytokines in patients with cardiovascular disease. Cardiovasc Diabetol 2006; 5: 1.

12.de Vos AM, Prokop M, Roos CJ, et al. Peri-coronary epicardial adipose tissue is related to cardiovascular risk factors and coronary artery calcification in postmenopausal women. Eur Heart J 2008; 29: $777-83$.

13. Chaowalit N, Somers VK, Pellikka PA, Rihal CS, Lopez-Jimenez F. Subepicardial adipose tissue and the presence and severity of coronary artery disease. Atherosclerosis 2006; 186: 354-9.

14. Jeong JW, Jeong MH, Yun KH, et al. Echocardiographic epicardial fat thickness and coronary artery disease. Circ J 2007; 71: 536-9.

15.Djaberi R, Schuijf JD, van Werkhoven JM, Nucifora G, Jukema JW, Bax JJ. Relation of epicardial adipose tissue to coronary atherosclerosis. Am J Cardiol 2008; 102: 1602-7.

16. Wu FZ, Chou KJ, Huang YL, Wu MT. The relation of locationspecific epicardial adipose tissue thickness and obstructive coronary artery disease: systemic review and meta-analysis of observational studies. BMC Cardiovasc Disord 2014; 14:62.

17. Vega GL, Chandalia M, Szczepaniak LS, Grundy SM. Metabolic correlates of nonalcoholic fatty liver in women and men. Hepatology 2007; 46: 716-22.

18. Shores NJ, Link K, Fernandez A, et al. Non-contrasted computed tomography for the accurate measurement of liver steatosis in obese patients. Dig Dis Sci. 2011; 56: 2145-51.

19. Iacobellis G, Assael F, Ribaudo MC, et al. Epicardial fat from echocardiography: a new method for visceral adipose tissue prediction. Obes Res 2003; 11: 304-10.

20. Ahn SG, Lim HS, Joe DY, et al. Relationship of epicardial adipose tissue by echocardiography to coronary artery disease. Heart 2008; 94: e7.

21.Sarin S, Wenger C, Marwaha A, et al. Clinical significance of epicardial fat measured using cardiac multislice computed tomography. Am J Cardiol 2008; 102: 767-71.
22.Demircelik MD, Yilmaz OÇ, Gurel OM, et al. Epicardial adipose tissue and pericoronary fat thickness measured with 64-multidetector computed tomography: potential predictors of the severity of coronary artery disease. Clinics 2014; 69: 388- 92.

23. Rumberger JA, Brundage BH, Rader DJ, Kondos G. Electron beam computed tomographic coronary calcium scanning: a review and guidelines for use in asymptomatic individuals. Mayo Clin Proc. 1999; 74: 243-52.

24. Raggi P. Coronary calcium on electron beam tomography imaging as a surrogate marker of coronary artery disease. Am J Cardiol 2001; 87: 27A-34A.

25. Alper AT, Hasdemir H, Sahin S, et al. The relationship between nonalcoholic fatty liver disease and the severity of coronary artery disease in patients with metabolic syndrome. Turk Kardiyol Dern Ars. 2008; 36: 376- 81.

26. Matteoni CA, Younossi ZM, Gramlich T, Boparai N, Liu YC, McCullough AJ. Nonalcoholic fatty liver disease: a spectrum of clinical and pathological severity. Gastroenterology 1999; 116: 1413- 19. 